\title{
Research on Financial Management Information Construction of Electric Power Enterprises in China
}

\author{
Qi JIANG ${ }^{1, a}$, Wei $\mathrm{HAO}^{2, \mathrm{~b},{ }^{*}}$, Jing $\mathrm{JIA}^{3, \mathrm{c}}$ \\ State Grid Shaanxi Province Electric Power Company Training Center, No.180.Changlexi Road, \\ Xi'an, 710032, China

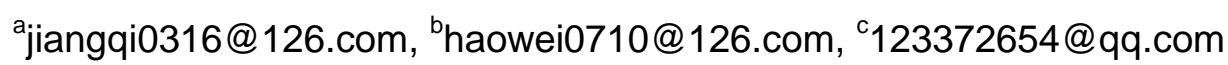 \\ *Corresponding author
} Keywords: Electric Power Enterprise, Financial Management Informatization, Problem and
Countermeasure.

\begin{abstract}
With the rapid development of China's national economy, the increasing trend of global economic integration is becoming more and more obvious. The competition of various industries is becoming more and more intense. As the pillar industry in China's national economy, the development of electric power enterprises is directly related to the people's livelihood Impact. In the context of the gradual separation of power generation and power grid, the electricity market has begun to open to the outside world. In the process of deepening the reform of China's electric power enterprise management system, the financial management work has also put forward the requirements of information management, and the management of power enterprises Information requirements are no longer a simple accounting computerization process, but a development of electric power enterprise financial management work modernization, scientific and information process. This paper analyzes and discusses the current situation of the financial management informationization of electric power enterprises, the problems existing in the financial management information of electric power enterprises and the effective measures of the financial management information management of electric power enterprises. Detailed discussion on how to do the power enterprise financial management information construction work.
\end{abstract}

\section{China's Electric Power Enterprise Financial Management Information Construction Status Quo}

At present, the development of finance management informationization of electricity enterprises in China is in good condition, but there are still some problems in the development. In order to better cope with these problems, the author has made the relevant word theory from the status of the financial management information construction in China. . First, the power enterprise infrastructure is better, the basic framework of financial management information has been formed. Electric power enterprises for information construction work is very important, specialized information technology sector for the power enterprise information construction has done a lot of practical work[1]. The complete network infrastructure is the solid foundation of the financial management information construction of the electric power enterprise. Secondly, the quality of information about the financial management of the power enterprises is high. In order to promote the development of accounting computerization, the electric power enterprises have done a lot of work in the training of basic talents. The training of information management talents of electric power enterprises has become an important cornerstone of information management of electric power enterprises. Once again, the financial management information and hardware infrastructure investment is large. The power enterprise financial management information construction hardware facilities investment is very large, due to the importance of power system to information construction and the impact of the reform and development of power enterprise system. In addition, the process of informationization of finance 
management of power enterprises in our country is slow, and the information foundation is weak, At present, China's power enterprises into financial accounting software enterprise, because the level is limited, can not make the software for data analysis and data processing ability into full play, so that the process of financial management informatization is slow, and the information base is weak.

\section{Problems Existing In The Process Of Informatization of Financial Management of Electric Power Enterprises in China}

\section{The Lack of Government Support, China's Financial Management Information System Is Not Perfect}

In recent years, China has promulgated a series of accounting systems for further standardizing the legal operation of enterprise financial management, such as "accounting basic work standard", "accounting file management approach" and "accounting software basic functional norms", As a new thing, but the financial management information system itself is not perfect, in the early stages of development at present, around the world to see many of the problems faced by financial management informationization in the process of constant exploration, the traditional financial system has been unable to meet the needs of the emerging financial management further, especially the demand of the electric power enterprise financial management. So for financial management informatization in the developing countries in the world to establish laws and regulations is to ensure that it corresponds to the healthy development of the advantageous safeguard, but the influence of the traditional accounting system for financial management system of information related to the relevant government departments lack of awareness, on the other hand, many related personnel do not know and pay attention to it. The rules and regulations are not really implemented in the enterprise management.

\section{The Lack of Strong Security Precautions}

Because the electric power enterprise financial management informationization is in a more open environment, which will make all information be accessed, and the access will reduce the safety factor. And for some technical problems, power companies lack the necessary security precautions. For the technical problems, the author believes that nothing more than the following aspects: On the one hand, financial information may be inadvertently attacked, modified, or even lost in the transmission process. If this situation occurs, it will bring unimaginable losses to the power enterprises; On the other hand instead of financial electronic data symbols, magnetic media instead of paper media, which will have higher requirements on environment and technology to save the media, the safety work of archival preservation will also have very high risk because of easily affected by the outside world.

\section{The Research And Understanding of Financial Management Information Is Insufficient}

To establish a perfect information management system in power enterprises, the large amount of engineering, involving a wide range, including the management of electric power enterprise production organization form, ways of capital operation, enterprise management mode and management concept etc.. The establishment of the information management system is huge and involved in many aspects. It must be paid attention to by the leaders of the electric power enterprises and the work of the management staff, so as to establish a perfect information management system. If the management of electric power enterprises lack the spirit of innovation and do not fully understand the core task of the construction of enterprise information management, it will affect the modern management of electric power enterprise informationization construction, resulting in the development of the electric power enterprises limited[2].

Financial management information is accompanied by a new knowledge economy era, the research on it is still in the initial stage, is not perfect, but our country electric power enterprise innovation 
ability is still relatively weak, the influence of the traditional financial management system deeply, lack of understanding of financial management information. According to the structure of the traditional financial management system, an economic business, repeated data storage financial information system to summarize the way for a business information, the traditional financial management system often has a certain lag.

\section{Information Overload Is Serious and Financial Decision Support Is Inadequate}

In the process of financial management information construction, the main problems of financial decision support system are concentrated in the financial decision support system is not perfect, information explosion phenomenon is frequent. In recent years, along with OA, CRM, capital management system, financial budget management and other systems to promote the application of decision-makers to provide a lot of information and data support, but each management information between their own, there is no sound financial decision support system Information data processing, analysis support, making the decision-makers face a lot of information and more difficult to identify the information conducive to financial decision-making, business information, data explosion phenomenon, leading to the current stage of financial management information to a large extent Is to help enterprises to achieve "data age" rather than "information age."

\section{Financial Data Is Difficult to Achieve Sharing}

The economic activities of production, sale, control and prediction, electric power enterprises are mainly represented by the unification of information flow, capital flow and logistics. To effectively control the "three stream", by financial department is not enough to use the software, various departments of power enterprises especially the business sector must put their business into the category of management information software, software function will be extended to all aspects of power management, so as to establish the financial information and other business information interface[3]. To share financial information and business information integration, in order to truly reflect the credible dec

ision information from all directions and multi levels. However, from the current situation, there are still the consciousness of management is not in place, the shortage of funds, lack of personnel, business chain and other reasons can not realize the integration of financial and business part of the electric power enterprises, which will affect the realization of electric power enterprise financial management informationization.

\section{Financial Management Personnel Knowledge Structure Can Not Keep Up with The Financial Management Information Development Requirements}

Because the financial management personnel knowledge structure is not perfect, it cannot meet the financial management information development. The current financial management personnel selection criteria are not unified, in the actual appointment process standards are greatly reduced, so that the financial management of the knowledge structure cannot keep up with the pace of financial management information development. Electric power enterprise financial management information is the combination of network and accounting, so the financial management staff not only need to grasp the necessary accounting information, but also to master the relevant knowledge of the network, so the quality of financial management also put forward higher requirements. In the power of the enterprise financial management team in this compound talent is very lacking, so this will be to a large extent restricted to the development of financial management information.

\section{Financial Management Information Is Still in The Accounting Management Level}

If only the current electric power enterprise informatization level, so most of the enterprises have already entered the accounting oriented stage, financial personnel's workload has been greatly reduced, but the application is just to stay in the initial stage of accounting computerization, in fact, it is still in the accounting management level, there are still great difficulty in advance of effective control and accurately reflect the business, but in hindsight can reflect the economic activities of 
enterprises. So, such as the use of fixed assets and the changes of the electric power enterprise, the system can get timely sharing and transmission, and through the established asset management system, cannot change for effective management of enterprise assets.

\section{Chapter Three to Strengthen China 'S Power Enterprises Financial Management Information Construction Proposals}

Recognizing the problems existing in the construction of financial management informatization of electric power enterprises in China, the author puts forward some suggestions on the construction of financial management informatization in China's power enterprises.

\section{Improve the System, Improve The Service Agencies}

The relevant state legal departments should be faster to develop a financial management for the power of the laws and regulations; In addition, we should also set up identification departments for the power companies in the implementation of financial management information security process. Relevant government departments in the continuous improvement of the financial system and the corresponding laws and regulations should also continue to strengthen law enforcement efforts, government departments not only to create a system should also continue to maintain the authority of the system, so that the system did not dare to cross the mine, Thus ensuring the power of enterprises in the development of information technology has a safe and secure legal environment. As the power companies should be allowed in the scope of the law can continue to develop their own, according to the legal system to constantly improve their own internal financial system, so that with our laws to adapt. On the other hand, information technology in the continuous development, continue to mature, so the relevant laws and information technology should be consistent with the pace of development, and ultimately achieve mutual promotion role.

\section{To Strengthen The Financial Management Information System Security}

To ensure the normal operation of information. For example, the improvement of internal security system, corporate employees of the financial confidentiality; information system software maintenance, software selection and maintenance must not be ignored. To ensure the safe and reliable operation of the financial management information system, we start from the details, the timely investigation of the security risks of the system, the information security of the financial data of the enterprise's requirements are relatively high, which is a major feature of information. For enterprises, in the implementation of the information process, once the security problems, will cause great losses to the operation of enterprises. Therefore, enterprises must do a good job of security protection of information systems. Ensure the normal operation of information technology. For example, the improvement of the enterprise's internal security system, the confidentiality of the enterprise's employees, and the maintenance of the information system software, must not be ignored in the selection and maintenance of software.

\section{To Enhance The Management of The Financial Management of Information Management Awareness}

The management and attention degree of financial management information management is directly related to the application of informationization in power enterprise. On the one hand the relevant departments of the country do a good job supporting the positive publicity and guidance, so that the power companies to recognize the importance of information technology, and financial management information for the development of enterprises. On the other hand should also strengthen the power enterprise management knowledge of the popularity and application of knowledge, so that the leadership of the power industry to realize the financial management information will be the operation of the power efficiency and efficiency will be greatly improved, but also For the power companies to provide reliable analysis of high-level decision-making data to help enterprises to develop a scientific 
enterprise strategic management and strategic objectives, improve work efficiency and management level. Is a change in financial management.

\section{To Strengthen The Enterprise's Internal Control System}

First of all to financial information resource control. Financial information is from the network server database system, so the network database system is the focus of the entire network financial system control objectives. Threats to the database system security factors include: the network system personnel inside and outside the database of unauthorized access. Followed by power financial system development control[4]. Generally speaking, the financial enterprise financial software is different from other software, is related to the financial management and management of electric power enterprises, to ensure that programmers do not engage in the financial work of the unit to ensure that the source program managers do not engage in financial work to ensure that financial data independence The final power enterprise financial system maintenance control. Power system maintenance, including software modifications, code structure changes and computer hardware and communication equipment maintenance, maintenance of the network system must be carefully planned and strictly recorded, the maintenance process should be set in each part of the necessary control, maintenance reasons And the nature of the report must be in writing, after approval to implement the amendment.

\section{To Improve The Financial Management of Financial Management Level}

Talent is the establishment of enterprise financial management information of the fundamental guarantee, the establishment of financial management information must be trained to master a certain degree of financial management expertise and related computer knowledge of the talent team, financial software maintenance and maintenance, the use of technology, Expertise. In the context of knowledge-based economy, the development of power companies can not do without talent. Financial management information development is inseparable from the management and information technology of the compound talents training. Electric power enterprises in order to achieve information technology must cultivate a number of flexible control of computer technology and management of new talent. Only in this way can we ensure the financial information and enterprise management of the effective combination, so as to further promote the continuous development of power enterprises to improve the competitiveness of their own power companies.

\section{A Reasonable Allocation of Resources, Increase Investment in Financial Information Software}

Under normal circumstances, the power of the enterprise financial accounting work is more complex, and with the enterprise business volume continues to increase, the enterprise's financial accounting workload has also been greatly improved. The traditional manual accounting method is less efficient and can not meet the needs of the information age, and if we can establish a good financial management information system, then it can save a lot of energy for business executives, greatly enhance Its work efficiency, so that these staff will be more energy into high-level management work. Therefore, the decision-making level of enterprises should increase the investment of financial information software, establish a sound financial management information system, the introduction of various types of financial evaluation index system, the enterprise efficient information management, to ensure that the power enterprises in the fierce Competitive market environment to survive and develop.

\section{To Develop A Unified Standard to Ensure The Sharing of Software}

In order to effectively avoid the enterprise software development work to repeat the problem, we must fully guarantee the software sharing and common. In the process of designing and developing the power enterprise software, we should first formulate a unified standard, and on the basis of fully analyzing the development of the enterprise itself, develop the corresponding accounting software to realize the integration of business process and financial information Management, scientific use of the enterprise's resources, to ensure the sharing of information data[5]. 


\section{Conclusion}

Through the above discussion, we have discussed and analyzed the details of the current situation of the financial management informationization of electric power enterprises, the problems existing in the financial management information of electric power enterprises and the effective measures of the financial management information management work of electric power enterprises. Financial management information system of electric power enterprise construction enterprise should pay full attention and recognition, timely update management concepts, the establishment of a comprehensive high quality and strong professional and technical staff, enhance staff understanding of financial management information, timely summary of the problems in the process of informatization construction to perfect and develop countermeasures, so as to ensure the construction of financial management informatization of the successful completion of the work. In the face of our country electric power enterprise financial management informatization construction exists many problems, the electric power enterprise management workers should start from the actual situation of the electric power enterprise analysis, for there are some now has yet to achieve financial management information construction of electric power enterprises should be how to make them change ideas attach importance to financial management informationization work, for some have achieved financial management information construction of electric power enterprises how to better improve the informatization construction work, only to grasp the key to achieve good really do a good job in financial information management in the end to do a good job of enterprise management to ensure the stable and orderly development.

\section{References}

[1] Power Transmission and Distribution Engineering Company financial management problems and solutions [J]. He Zhengyi. Modern economic information .2016 (15)

[2] Analysis of the financial management of electric power enterprises [J]. Wang Jin. Science and technology innovation and application .2014 (19)

[3] Analysis of financial management in power enterprise internal control of the effective application [J]. Deng Jianming. Modern economic information .2013 (17)

[4] to strengthen the financial management of power generation enterprises [J]. Ning Jie. Management Manager .2013 (17)

[5] New period to strengthen the power supply company's financial management ideas [J]. Cao Ziqiang. Management manager .2013 (08) 